\title{
HYDROGEOPHYSICAL STUDY OF THE GROUNDWATER POTENTIAL OF ILARA-MOKIN SOUTHWESTERN NIGERIA
}

\section{I. OLADAPO, O.O. ADEOYE-OLADAPO, AND K. A. MOGAJI}

(Received 24, August 2007; Revision Accepted 6, March 2009)

\begin{abstract}
Geoelectric study of the groundwater potential of Ilara-Mokin in Ondo State Southwestern Nigeria was carried out using electrical resistivity (Vertical Electrical Sounding) method with the view to providing adequate information on the different sub-surface geoelectric layers, structural configuration of the concealed basement rocks and the groundwater potential of the study area.

Forty-one Schlumberger vertical electrical soundings (VES) were conducted across the study area. The computer assisted VES data interpretation enabled generation of geoelectric curves, sections and overburden thickness map which were used in the delineation of key hydrogeologic features like the topsoil, weathered basement, fractured basement and the fresh basement. Resistivity values range from $21 \Omega-m$ to $798 \Omega-m$ in the topsoil, $14 \Omega$-m to $209 \Omega$ $\mathrm{m}$ in the weathered basement, $51 \Omega-\mathrm{m}$ to 209 in the partially weathered/fractured basement and $312 \Omega-\mathrm{m}$ to $\infty$ within the fresh basement. Layer thickness values also vary from $0.3 \mathrm{~m}$ to $6.1 \mathrm{~m}$ in the topsoil and $0.9 \mathrm{~m}$ to $28.6 \mathrm{~m}$ in the weathered basement. The depth to the resistive bedrock ranges from $0.3 \mathrm{~m}$ to $29.3 \mathrm{~m}$ across the study area.

The study revealed that greater part of llara-Mokin town is underlain by marginally thick overburden thus constituting shallow aquifer units with poor to marginal groundwater potential. Partially weathered/fractured basement were delineated in isolated cases with tendency for low to marginal groundwater yield around central and northeastern areas of the town. The results reasonably provide basic information that is expected to assist in the future development of groundwater resources in Ilara-Mokin.
\end{abstract}

KEYWORDS: electrical resistivity, hydrogeologic, geoelectric, bedrock and weathered basement

\section{INTRODUCTION}

The study area, Ilara-Mokin in Ondo State, Southwestern Nigeria, is a developing town situated on a basement terrain with inadequate potable water supply. The population of the town is increasing with establishment of a polytechnic in the community and the proximity of a Federal University. The populace depends mainly on groundwater resources for their domestic needs.

The electrical resistivity method is one of the most popular of the several non-invasive geophysical prospecting methods commonly used for groundwater studies (Zohdy, 1969; Flathe, 1970; Verma et al, 1980; De Beer and Blume, 1985; Olayinka and Barker 1990; Yang et al, 1994; Moller et al, 1998; Omosuyi et al, 2003; Ekwe et al, 2006; Oladapo and Akintorinwa, 2007). The electrical resistivity is a physical property of rocks and soils most affected by the presence of water. Variation in groundwater chemistry may also affect the electrical properties (Mota, et al., 2004). However, groundwater investigations in basement complex areas are often more difficult, as wide variations of aquifer parameters characterize the groundwater regime. Spatial variations of these characteristics are attributable to, among other causes, tectonism and degree of weathering of the basement rocks (Barker et al., 2001). The Schlumberger vertical electrical sounding adopted in this study is popular for determining the resistivity variation with depth. Beeson and Jones (1988), Olayinka and Barker (1990), Hazell et al. (1988 and 1992), Barker et al. (1992), Carruthers and Smith (1992) and Olayinka and Olorunfemi, (1992) have demonstrated the use of electrical resistivity method for siting wells and boreholes in crystalline basement terrain.

In this study, a hydrogeophysical evaluation of the area around llara-Mokin was carried out. The study was undertaken to determine the geoelectric parameters in form of layer resistivities and thicknesses of the superficial/overburden materials overlying the basement bedrock and the structural framework of the bedrock. The geoelectric parameters were used to generate geoelectric sections and maps.

\section{Description of Study Area}

Ilara-Mokin is located along Ilesha-Akure motorway and it is situated about 5 kilometers west of Akure metropolis. The town is situated within latitudes $\mathrm{N} 07^{\circ} 21^{\prime} 16^{\prime \prime}$ and N07 $22^{\prime} 20^{\prime \prime}$ and longitudes E005 $05^{\prime}$ $58^{\prime \prime}$ and $\mathrm{E} 005^{\circ} 07^{\prime} 12^{\prime \prime}$. There are also other minor roads that connect llara-Mokin to other rural towns and villages around it. The towns and villages around llara-Mokin include Igbaraoke, ljare, Isharun, Ipogun, Ikota and Ipinsa.

\section{Geology and Geomorphology}

Ilara-Mokin is underlain by rocks of the Precambrian Basement Complex of Southwestern Nigeria (Figure 1) (Rahaman, 1976). The lithological units include variably migmatized biotite-hornblendegneiss with intercalated amphibolite. Low lying outcrops of migmatite-gneiss complex are situated on the western and northeastern parts of the town while boulders of amphibolites/charnockite rocks are located in the central and north central areas of the town. 


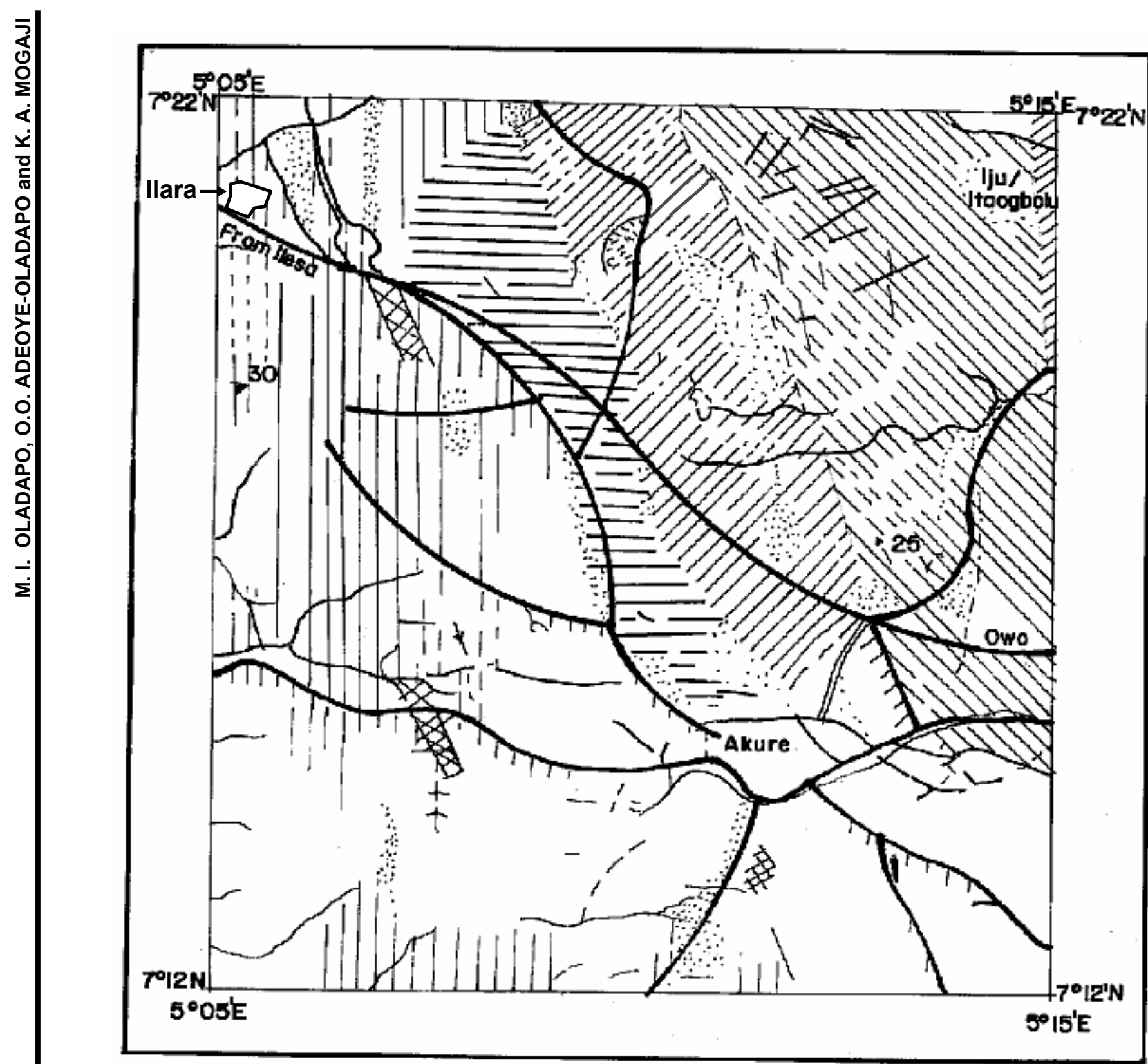

\section{LEGEND}

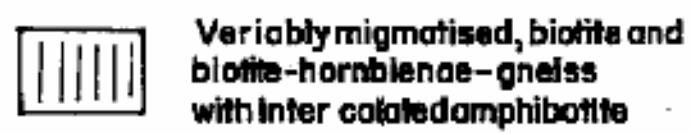

\section{㝖宛 Quartzite}

Medium to coarse-grained biotite grantre

\section{Coarse porphyritic biotite and biotite hornbienge-granite}

Fine to medium grainec biotite and blotitemescovite-gronlite

\section{ـ Major quartz veing}

_ - _ Beological boundary, approximane

Geological boundary, uncerlain

C Strike and dip of foliotion

- Strike of vertical foliation

- Horizontal foliation

Plunge of minor folds and lineotion

-_ Fault, approximately

$\underset{\sim}{\sim}$ Structuroltrend

$\nabla$ Study Area

$5 \mathrm{~km} \quad \stackrel{0}{5} \quad 5 \mathrm{~km}$

Fig. 1: Geological map of Akure environ showing the study area. 
The study area is situated on gently undulating terrain with elevation between $336 \mathrm{~m}$ and $350 \mathrm{~m}$ above mean sea level. The region which lies within the tropical rainforest of Nigeria is characterized by two distinct seasons (wet from March to October and dry from November to February). The annual mean rainfall is about $1800 \mathrm{~mm}$. The annual mean temperature ranges between $24^{\circ} \mathrm{C}$ and $27^{\circ} \mathrm{C}$.

\section{Hydrogeology}

Regolith and fractured basement generally occur in a typical basement terrain (Odusanya and Amadi, 1990). In tropical and equatorial regions, weathering processes create superficial layer with varying degree of porosity and permeability. Studies have shown that the unconsolidated overburden could constitute reliable aquifer if significantly thick (Satpathy and Kanungo, 1976, Offodile, 1983: Olorunfemi and Olorunniwo, 1985; Dan-Hassan and Olorunfemi, 1999; Bala and lke, 2001). Also the concealed basement rocks may contain highly faulted and folded area, incipient joints and fracture systems derived from multiple tectonic events they have experienced. These structures may house abundant groundwater in a typical basement setting. Detection and delineation of such structural features may facilitate the location of groundwater prospect zones (Omosuyi et al., 2003).

\section{MATERIALS AND METHOD OF STUDY}

Field data acquisition was undertaken along existing road paths using ABEM SAS 1000 Terrameter. Forty-one (41) vertical electrical sounding (VES) locations were occupied within the town (Fig. 2) utilizing the schlumberger electrode configuration. Electrode spacing $(A B / 2)$ was varied from $1.0 \mathrm{~m}$ to $100 \mathrm{~m}$. The VES data were utilized in generating field curves. The curves were interpreted using partial curve matching technique. The geoelectric parameters obtained from manual interpretation of each VES curve were refined using the software algorithm RESIST version 1.0 (Vander Velpen, 1988).

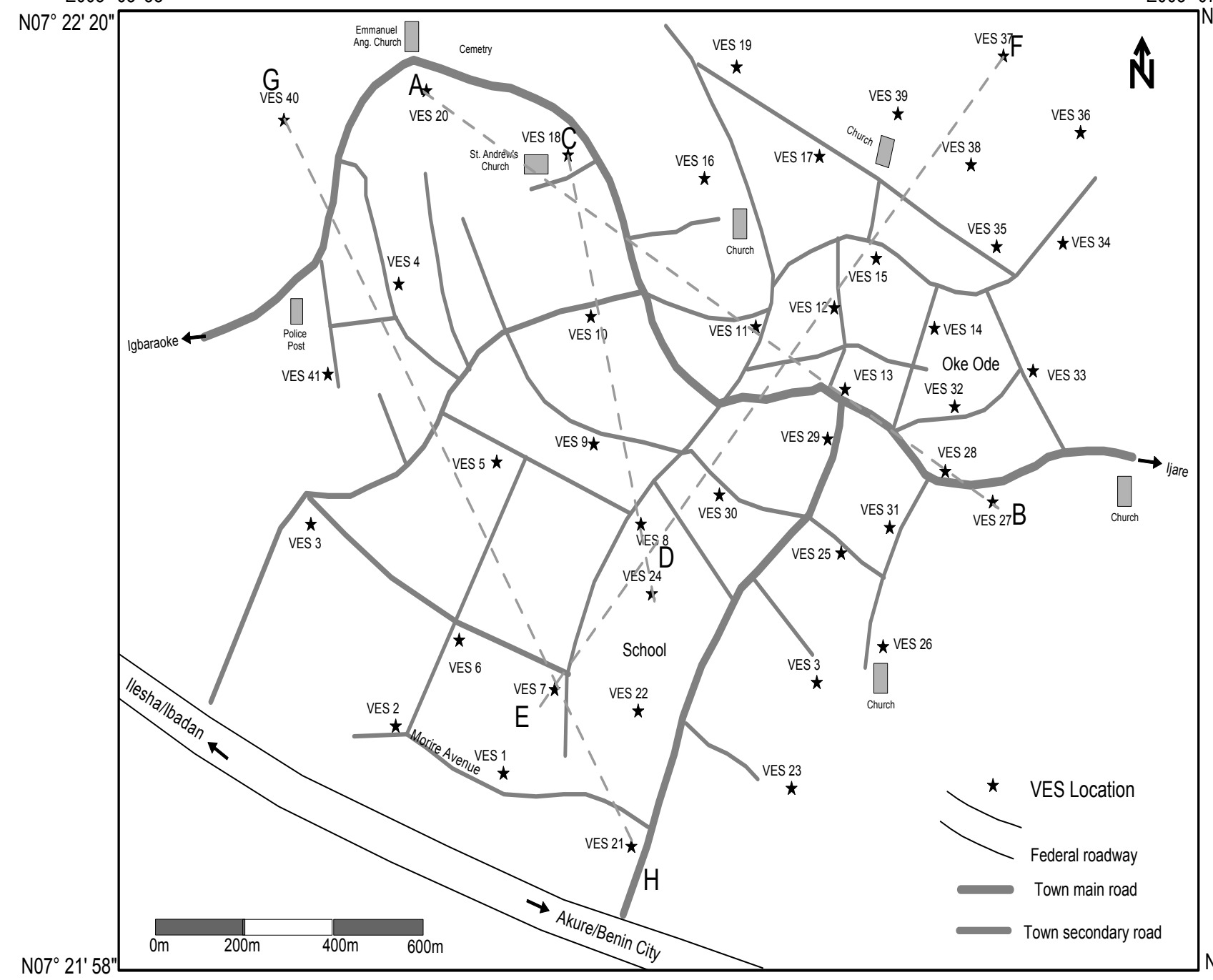




\section{RESULTS AND DISCUSSION}

The results of the study are presented as sounding curves, geoelectric sections and overburden thickness map. The curve types obtained from the study area are the $\mathrm{H}, \mathrm{A}, \mathrm{K}, \mathrm{HK}, \mathrm{HA}, \mathrm{QH}$ and HKH type. The $\mathrm{HKH}$ curve type in a typical basement environment in many instances, indicates fracturing and presents favourable zones for groundwater abstraction (Oladapo et al., 2004). The A-type curves are characterized by a steady rise in resistivity profile from topsoil to the bedrock while the intermediate layer in the $\mathrm{H}$-type is commonly water saturated and is often characterized by low resistivity, high porosity, low specific yield and low permeability (Jones, 1985; Olayinka and Olorunfemi, 1992). The typical VES curves obtained from the study are presented in Figure 3
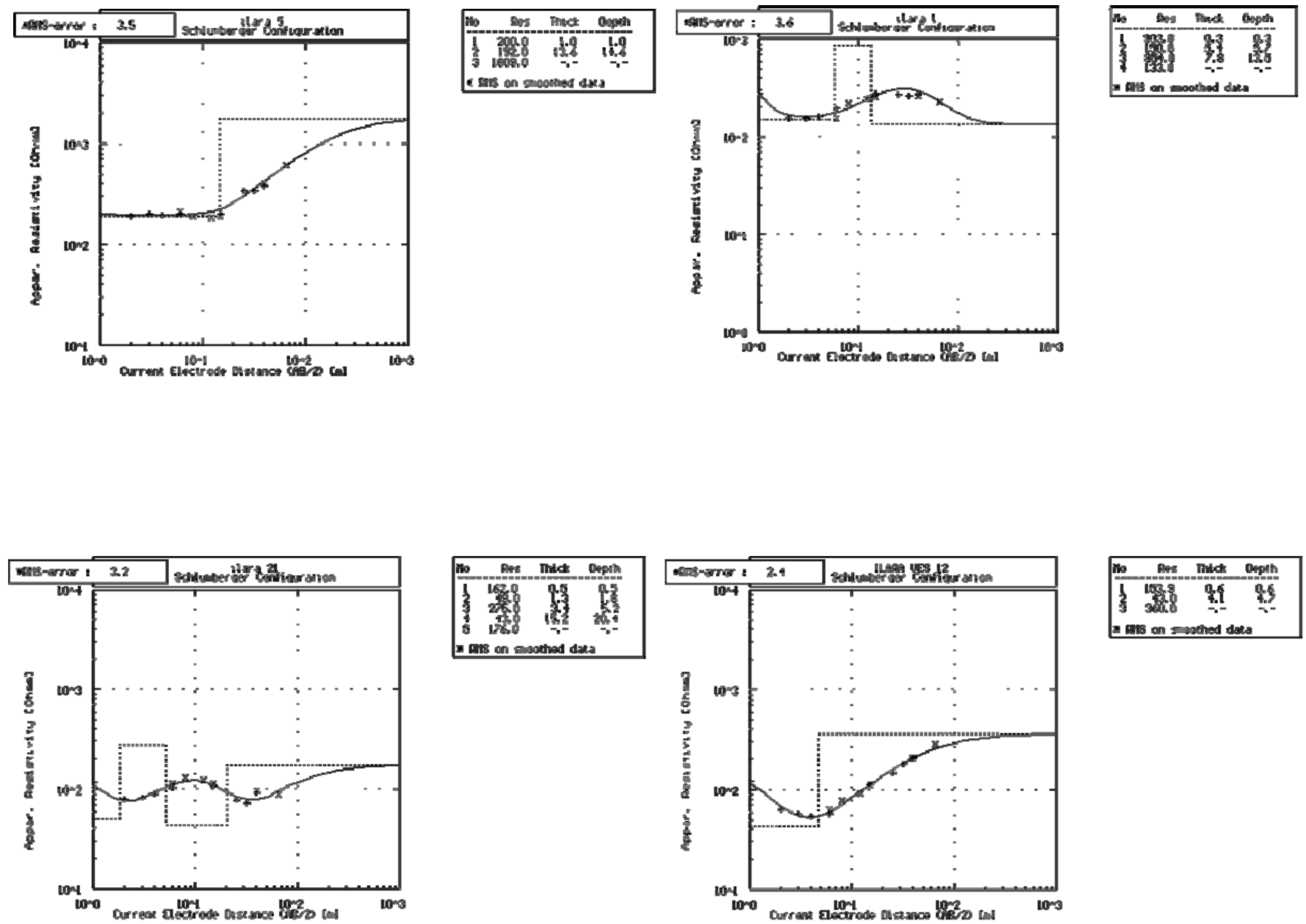

Fig. 3: Typical sounding curves obtained from llara-Mokin

The first order parameters obtained in form of layer thicknesses and resistivity values from the interpretation of the field curves (see Table 1) were utilized in generating geoelectric sections and overburden thickness map. The geoelectric sections taken along four directions (A-B, C-D, E-F and G-H in Figure 2) showed that four subsurface geologic layers consisting of topsoil, weathered basement, fractured basement and fresh basement underlie llara-Mokin. The section along profile $A-B$ is about $1300 \mathrm{~m}$ long and connects VES $20,18,11,13,28$ and 27 along NW-SE azimuth (Fig. 4). The topsoil resistivity values range from $27 \Omega-\mathrm{m}$ to $798 \Omega-\mathrm{m}$. The low resistivity $(<100 \Omega-\mathrm{m})$ is characteristic of clay while the fairly high resistivity values $(>100 \Omega-m)$ may typify sandy clay, clayey sand and laterite. Topsoil thickness ranges from $0.4 \mathrm{~m}$ to 1.0 $\mathrm{m}$ along this section.

The second layer (weathered basement) resistivity values vary from $14 \Omega-m$ to $181 \Omega-m$. The electrical resistivity values of this layer are controlled by the degree of water saturation (Odusanya and Amadi, 1990) and also degree of shaliness. Significant saturation may induce reduction in resistivity. The thickness of the second layer varies from $1.4 \mathrm{~m}$ to $12.9 \mathrm{~m}$.

The fresh basement resistivity varies from $361 \Omega$ $m$ to $\infty$. VES 13 exhibits the thickest overburden (13.3 $\mathrm{m})$ within the section. However the weathered materials are characterized by low resistivity $(44 \Omega-m)$ indicative of clay. Thus, poor hydrogeoelectric characteristics exist along the section. 
Table 1: Summary of Results obtained from Ilara-mokin Geoelectric Study

\begin{tabular}{|c|c|c|c|}
\hline $\begin{array}{l}\text { VES } \\
\text { No }\end{array}$ & Location Description & $\begin{array}{l}\text { Depths }(\mathrm{m}) \\
\mathrm{D}_{1} / \mathrm{D}_{2} / \ldots \ldots \mathrm{D}_{\mathrm{n}-1}\end{array}$ & $\begin{array}{l}\text { Resistivity Values } \rho_{\mathrm{a}}(\Omega-\mathrm{m}) \\
\rho_{1} / \rho_{2} \ldots \ldots / \rho_{\mathrm{n}}\end{array}$ \\
\hline 1 & Morire Avenue & $0.7 / 2.0 / 17.3$ & $337 / 94 / 307 / 173$ \\
\hline 2 & Undeveloped Area & $6.1 / 28.2$ & $268 / 1905 / 603$ \\
\hline 3 & Hospital Road & $2.7 / 9.5$ & $44 / 119 / \infty$ \\
\hline 4 & St. John Pry Sch/Alafiatayo Str & $1.1 / 2.8 / 21.1$ & $102 / 47 / 445 / 72$ \\
\hline 5 & Iloro Street & $0.9 / 14.7$ & 200/193/1868 \\
\hline 6 & Klova Street & $3.9 / 5.3$ & $179 / 165 / \infty$ \\
\hline 7 & Klova Street/Olorunfemi Str & $1.0 / 10.1 / 18.7$ & $62 / 363 / 209 / \infty$ \\
\hline 8 & Iloro/Olorunfemi Str Junction & $0.9 / 2.2$ & $91 / 61 / \infty$ \\
\hline 9 & Ifelodun Street & $0.4 / 3.2$ & $144 / 31 / 312$ \\
\hline 10 & Hospital Road & 0.3 & $90 / \infty$ \\
\hline 11 & Christ Love Hosp. Odo Igbeyin & $0.4 / 2.9$ & $55 / 14 / 361$ \\
\hline 12 & Opokiti Street & $0.6 / 4.7$ & $154 / 43 / 360$ \\
\hline 13 & Market & $0.4 / 13.3$ & $140 / 44 / \infty$ \\
\hline 14 & Ajigunse Street & 9.2 & $51 / \infty$ \\
\hline 15 & Oke Ode & $0.5 / 15.0$ & $141 / 63 / \infty$ \\
\hline 16 & St Michael Anglican Church & $0.8 / 3.4$ & $234 / 15 / \infty$ \\
\hline 17 & Araromi Street & 0.9/6.1/15.6 & $21 / 78 / 32 / \infty$ \\
\hline 18 & St Andrew Anglican Pry School & $0.5 / 1.9$ & $798 / 19 / \infty$ \\
\hline 19 & Risemola Farm & $0.6 / 9.3$ & $170 / 74 / \infty$ \\
\hline 20 & Emmanuel Ang Pry Sch Ayede & $1.0 / 7.2$ & $233 / 181 / \infty$ \\
\hline 21 & United Bank for Africa & $0.6 / 1.7 / 5.0 / 29.3$ & $153 / 42 / 285 / 49 / 366$ \\
\hline 22 & Muslim Primary School & $0.7 / 3.1$ & $203 / 65 / \infty$ \\
\hline 23 & Ajiluyi Street & $0.7 / 2.9$ & $135 / 28 / \infty$ \\
\hline 24 & Iloro Street & $1.6 / 4.1$ & $66 / 47 / 458$ \\
\hline 25 & Oke Peti & $1.8 / 15.3$ & $80 / 29 / \infty$ \\
\hline 26 & Oke Peti & $0.9 / 12.0$ & $107 / 418 / 2605$ \\
\hline 27 & Oke Ode & $0.8 / 4.6$ & $116 / 39 / 1292$ \\
\hline 28 & Oke Ode & $0.6 / 8.1$ & $27 / 24 / \infty$ \\
\hline 29 & Mokin Street & $0.6 / 5.5$ & $93 / 27 / \infty$ \\
\hline 30 & Ifelodun Street & $1.1 / 7.9$ & $28 / 60 / \infty$ \\
\hline 31 & Oke Eruku Street & $0.8 / 3.1$ & $54 / 74 / \infty$ \\
\hline 32 & Oke Ode Street & 0.5/1.6/3.8/10.4 & $92 / 24 / 81 / 23 / \infty$ \\
\hline 33 & Oke Ode Street & $1.1 / 9.9$ & $58 / 38 / \infty$ \\
\hline 34 & Oke Ode Street & $2.0 / 13.7$ & $30 / 56 / \infty$ \\
\hline 35 & Oke Ode Street & $0.9 / 2.9$ & $32 / 73 / \infty$ \\
\hline 36 & Iro Street & $0.6 / 11.0$ & $151 / 43 / 474$ \\
\hline 37 & Oke Iro Street & $0.4 / 7.2$ & $84 / 40 / \infty$ \\
\hline 38 & Oke Iro Street & $0.7 / 3.1$ & $53 / 39 / 713$ \\
\hline 39 & Araromi Street & $0.4 / 1.4$ & $412 / 37 / \infty$ \\
\hline 40 & West of cemetery (Hand-pump well) & $1.0 / 18.7$ & $287 / 460 / 31$ \\
\hline 41 & Adekola Street/Abebi Qtrs & $0.9 / 14.6$ & $147 / 637 / 1134$ \\
\hline
\end{tabular}

The section along profile C-D which is $470 \mathrm{~m}$ long (Figure 5) comprises VES 18, 10, 9, 8 and 24 along the NNW-SSE azimuth. Topsoil resistivity values along the section range from $61 \Omega-m$ to $798 \Omega$-m with thickness varying between $0.3 \mathrm{~m}$ and $1.6 \mathrm{~m}$. 
A

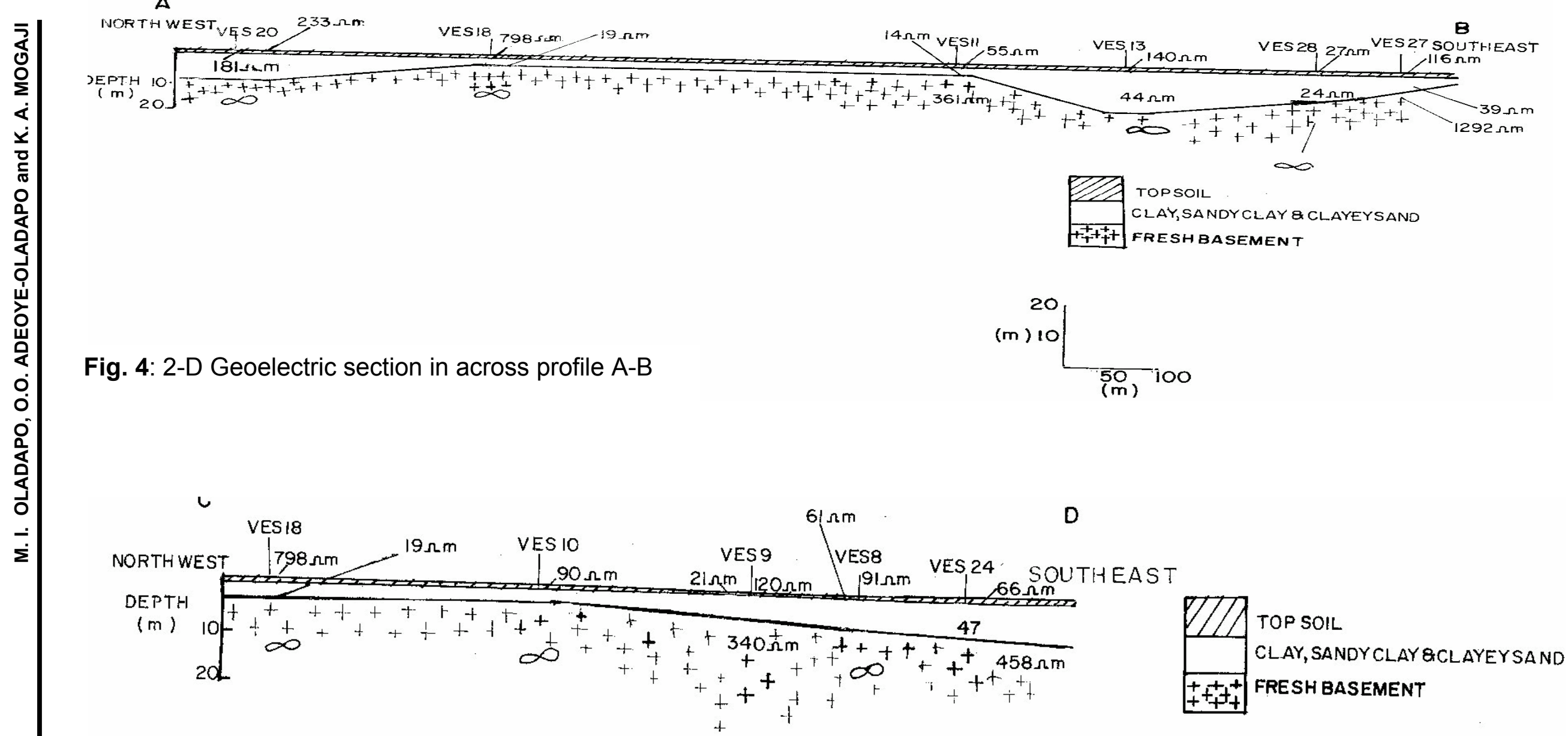

Fig. 5. 2-D Geoelectric section in across profile C-D

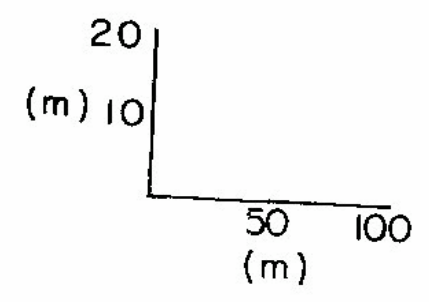


The weathered basement resistivity values vary from $19 \Omega-m$ to $61 \Omega-m$ while the thickness of the layer varies from $0 \mathrm{~m}$ to $2.5 \mathrm{~m}$. The fresh basement resistivity varies from $340 \Omega-m$ to $\infty$. The geoelectric characteristics along the $\mathrm{C}-\mathrm{D}$ section present very poor hydrogeological setting.
The section along profile E-F is presented in Figure 6. This section comprises VES 7, 24, 30, 12, 15, 38 and 37 along SW-NE azimuth. Topsoil resistivity values in the E-F section range from $28 \Omega-m$ to $154 \Omega-m$ while layer thickness ranges from $0.4 \mathrm{~m}$ to $1.6 \mathrm{~m}$.

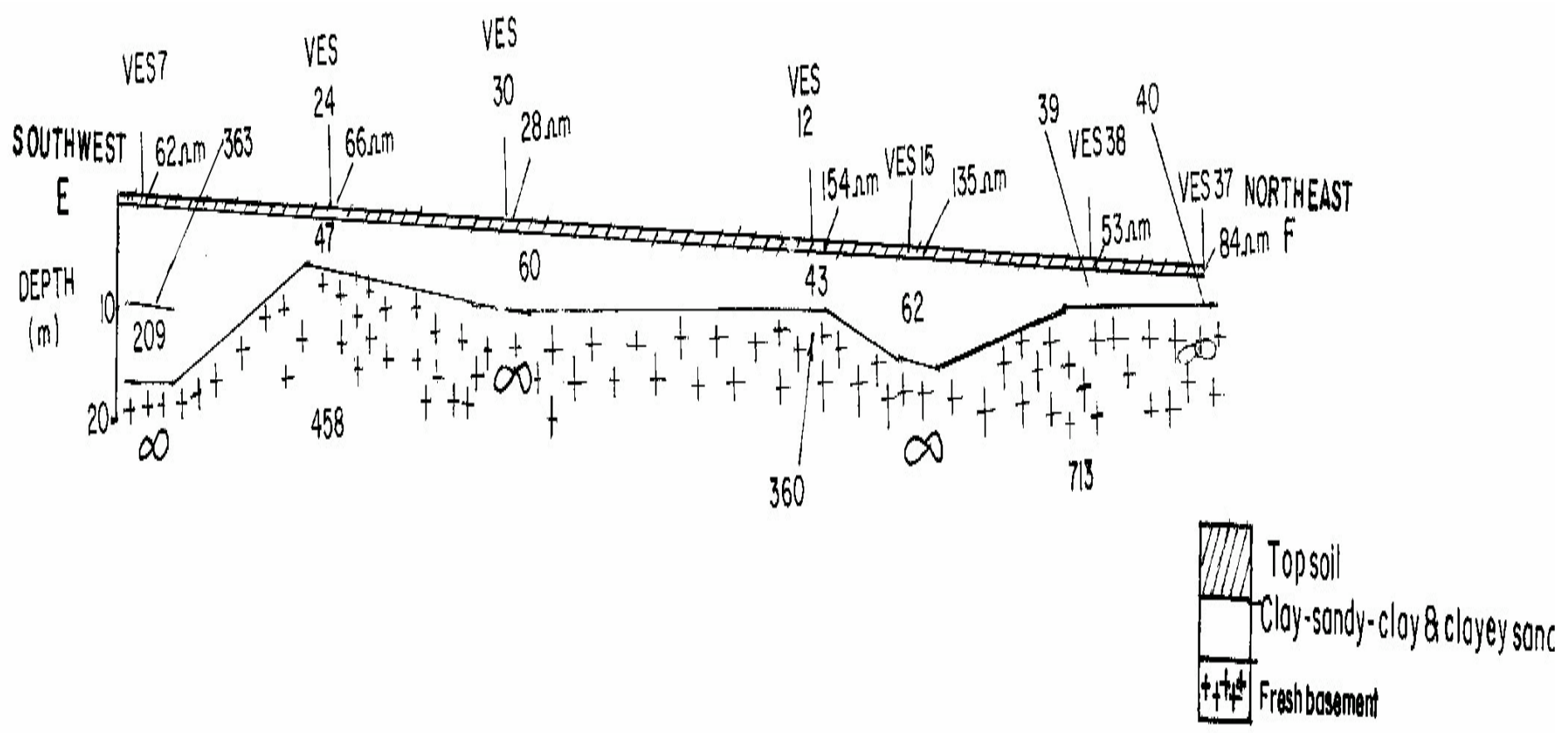

Fig. 6: 2-D Geoelectric section in across profile E-F

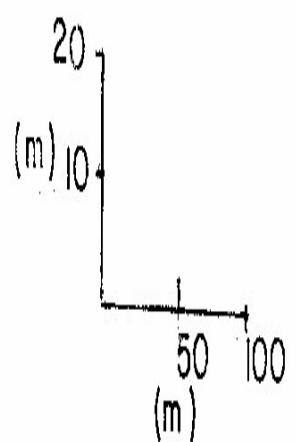

The second layer constitutes the weathered basement and is characterized by resistivity values ranging from $39 \Omega-\mathrm{m}$ to $363 \Omega-\mathrm{m}$. The thickness of the weathered layer varies from $2.4 \mathrm{~m}$ to $16.7 \mathrm{~m}$. The fresh basement has resistivity values ranging from $360 \Omega-m$ to $\infty$. The weathered materials underlying E-F section are fairly thin and characterized by low resistivity values that may not facilitate sufficient groundwater accumulation.

The section along profile $\mathrm{G}-\mathrm{H}$ which is presented in Figure 7 comprises VES 40, 4, 5, 7 and 21 and is oriented along NW-SE azimuth. The topsoil resistivity values in the section range from $62 \Omega-m$ to $287 \Omega-m$ with layer thickness ranging between $0.5 \mathrm{~m}$ and $1.3 \mathrm{~m}$. The second layer which is the weathered basement has resistivity values varying from $42 \Omega-m$ to $193 \Omega-m$. The thickness of the weathered layer varies between $0 \mathrm{~m}$ at VES 40 and $13.8 \mathrm{~m}$ at VES 5. Fracture bedrock columns were observed at VES 7 and VES 21. The fractured basement resistivity values range from $50 \Omega-m$ to $209 \Omega$ $\mathrm{m}$ while the fresh basement has resistivity values in excess of $366 \Omega-\mathrm{m}$. The combination of weathered and fractured basement beneath VES 7 and 21 in this section constitute relatively deep but clayey aquifer units that may enhance groundwater accumulation. 


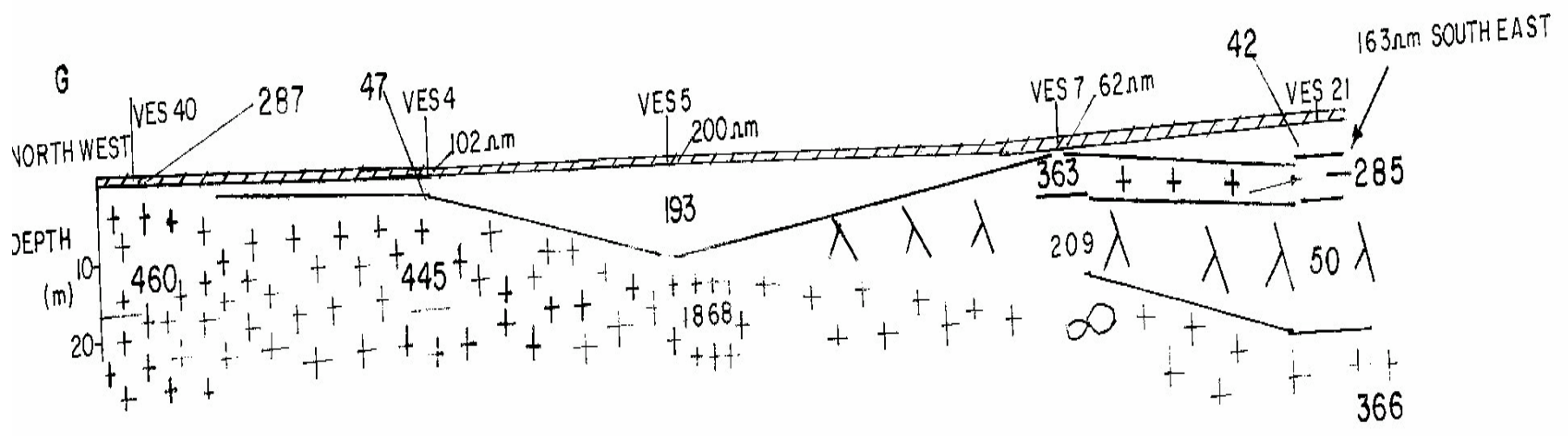

Fig. 7: 2-D Geoelectric section in across profile G-H

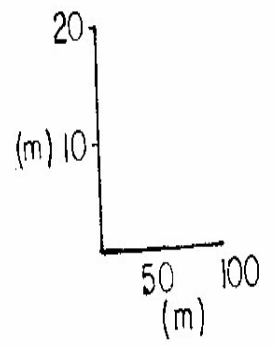

\section{Overburden Thickness map}

The overburden thickness map of the study area is presented in Figure 8. Thickness of the overburden in Ilara-Mokin varies between $0.3 \mathrm{~m}$ at VES 10 (northern flank of Hospital Road) and $17.3 \mathrm{~m}$ at VES 17 (Araromi Street). The map was utilized for hydrogeologic characterization of the study area based on overburden thickness values. Thus the town is classified hydrogeologically into poor (thickness $<10.0 \mathrm{~m}$ ) and marginal (thickness $>10.0 \mathrm{~m}$ ). The map shows that Ilara-Mokin is generally underlain by thin weathered basement rocks. Areas of thin overburden (central, northwestern, western and eastern flanks) are defined by blank background in the map. Areas of relatively thick overburden are defined by vector pattern. The marginal thickness areas which are in isolated patterns are situated on the central and northeastern areas of the town.

\section{Groundwater Potential Evaluation}

The groundwater potential of Ilara-Mokin was evaluated based on the geoelectric sections (Figures 4 to 7) and overburden thickness map (Figure 8) generated from the characteristic geoelectric parameters, obtained from the VES interpretation results. The map as hatched presents local groundwater prospect of the town classified into poor and marginal potentials. The map shows that poor groundwater potential zones (areas of thin overburden) are ubiquitous in the town (blank pattern areas of figure 8 ). The works of Okhue and Olorunfemi, (1991) and Bala and Ike, (2001) indicated that areas underlain by thick and sandy (relatively permeable) overburden materials are high groundwater potential zones. Such high groundwater potential zones are however absent in Ilara-Mokin. 


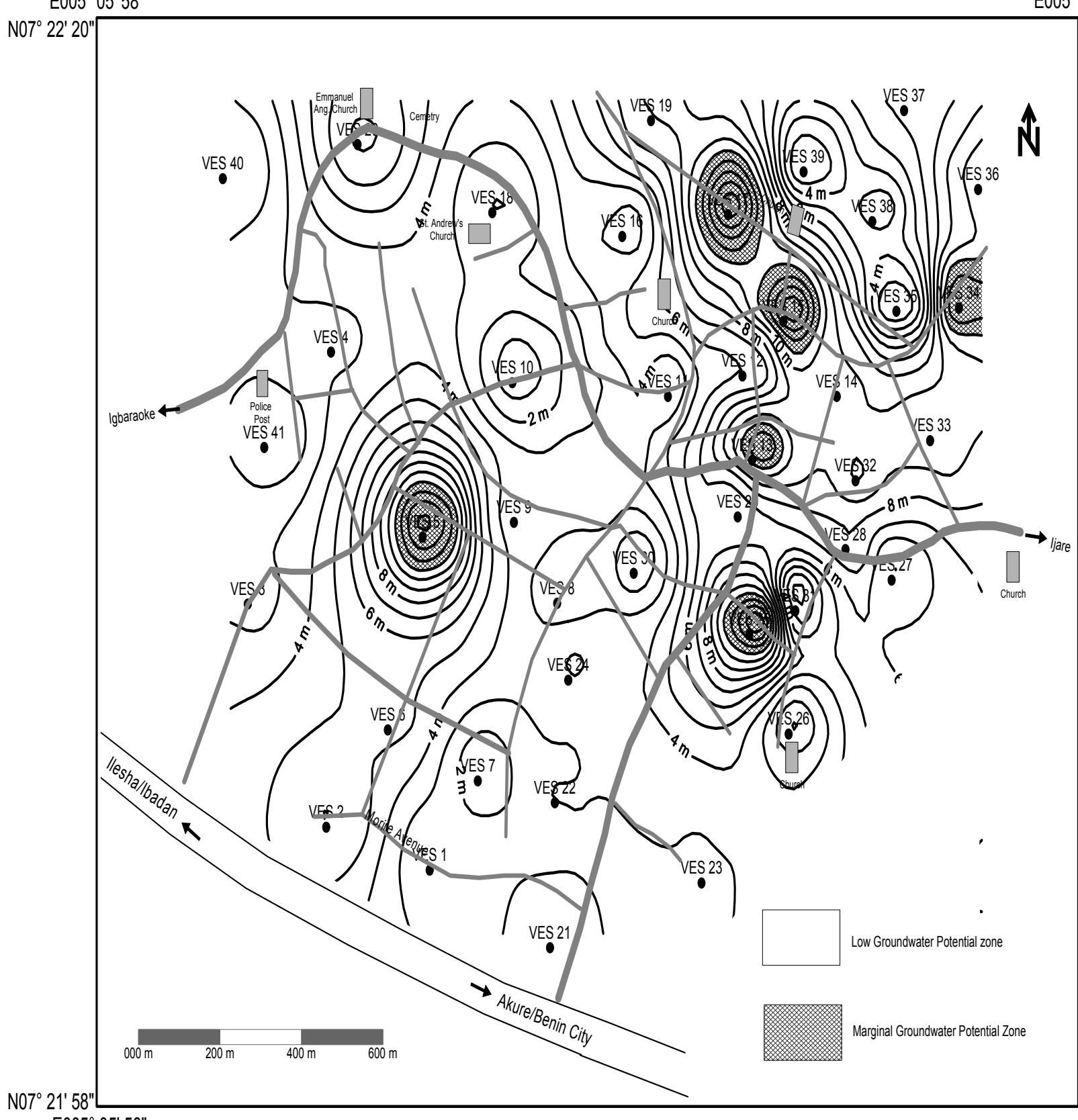

$\mathrm{E} 005^{\circ} 05^{\prime} 58^{\prime \prime}$

Fig. 8: Overburden thickness map of Ilara-Mokin

\section{CONCLUSION}

In this study, the hydrogeologic evaluation of Ilara-Mokin has been undertaken. The study revealed that marginal groundwater potential zones only exist in isolated structures around Iloro Street in the central area and Oke Ode, Araromi, Oke Peti and Iro in the northeastern area of the town. Unfavourable hydrogeologic setting is prevalent

in Ilara-Mokin. The VES stations underlain by marginal groundwater potential zones are envisaged to be marginally viable for groundwater development. No area of Ilara-Mokin can be classified as medium or high groundwater potential zone. The zones delineated as marginal groundwater potential zones in this study should therefore constitute priority areas for groundwater development in llara-Mokin.

\section{REFERENCES}

Bala, A.N and Ike, E. C., 2001. The aquifer of the crystalline basement rocks in Gusau area, North-western Nigeria. Journal of Mining and Geology, 37(2): 177184.

Barker, R, RAO T V and Thangarajan, M. 2001. Delineation of contaminant zone through electrical imaging technique; Curr. Sci. 81(3):7y 277-283. 
Barker, R. D., White, C. C. and Houston, J. F. T., 1992. Borehole Siting in an African Accelerated Drought Releif Project. In: E. P. Wight and W. G. Burgess, (eds), The Hydrogeology of Crystalline Basement Aquifers in Africa. Geological Society Special Publication, 66: 183-201.

Beeson, S. and Jones, C. R. C., 1988. The Combined EMT/VES Geophysical Method for Sitting Boreholes. Ground Water, vol. 26 (1):54-63.

Carruthers, R. M. and Smith, I. F., 1992. The Use of Ground Electrical Methods for Siting Water Supply Boreholes in Shallow Crystalline Basement Terrains. In: E. P. Wight and W. G. Burgess, (eds), The Hydrogeology of Crystalline Basement Aquifers in Africa. Geological Society Special Publication, 66: 203-220.

Dan-Hassan, M. A. and Olorunfemi, M. O., 1999. Hydrogeophysical investigation of a basement terrain in the north central part of Kaduna State Nigeria. Journal of Mining and Geology, 35 (2): 189 - 206.

De beer, J. H. and Blume J., 1985. Geophysical and Hydrogeological investigations of the Ground-water resources of Western Hereroland, South West Africa/Namibia Trans Geol. Soc. S. Africa, 88: 483 493

Ekwe, A.C. Onu N.N. and Onuoha K. M., 2006. Estimation of aquifer hydraulic characteristics from electrical sounding data: the case of middle Imo River basin aquifers, South- eastern Nigeria. Journal of Spatial Hydrology, 6 (2): 121-132

Flathe, H., 1970. Interpretation of Geoelectrical Resistivity Measurements for Solving Hydrogeological Problems. In Morely, E. W. (ed.), Mining and Groundwater Geophysics: Geological Survey of Canada Economic Geological Report, no. 26: 580-597.

Hazell, J. R. T., Cratchley, C. R. and Jones, C. R. C., 1992. The hydrogeology of Crystalline Aquifers in Northern Nigeria and Geophysical Techniques used in their Exploration. In: E. P. Wight and W. G. Burgess, (eds), The Hydrogeology of Crystalline Basement Aquifers in Africa. Geological Society Special Publication, No. 66, pp. 155-182.

Hazell, J. R. T., Cratchley, C. R. and Preston, A. M., 1988. The Location of Aquifers in Crystalline Rocks and Alluvium in Northern Nigeria using Combined Electromagnetic and Resistivity Techniques. Quarterly Journal of Engineering Geology, 21: 159175.

Jones, M. J., 1985. The weathered zone aquifers of the basement complex areas of Africa. Quarterly Journal of Engineering Geology. Pp $35-46$.

Moller, I., Sorensen, K., and Christensen, N., 1998. DC Resistivity Multi-Electrode Profiling in Hydrogeological Investigations: A Comparative Study of the Pulled-Array Continuous Electrical Sounding Method and a MultiElectrode Method with Fixed Electrodes. Symposium on the Application of Geophysics t Environmental and Engineering Problems, pp. 869-874.

Mota, R,, Monteiro-Santos, F. A., Mateus, A., Marques, F. O., Gonclave, M. A. and Figuerias Amaral, J. H., 2004. Granite fracturing and incipient pollution beneath recent landfill facilities as detected by geoelectric surveys. Journal Applied Geophysics. 57: 11-22

Odusanya, B.O. and Amadi, U., 1999. An empirical resistivity model for predicting shallow groundwater occurrence in the basement complex. Water Resource Journal of Nigeria Association of Hydrogeology, 2: 77-87

Offodile, M. E.., 1983. The occurrence and Exploration of Groundwater in Nigeria Basement rocks, J. Min. Geol. 20 (1 and 2): 131-146.

Oladapo, M . I., Mohammed, M. Z., Adeoye, O. O. and Adetola, B. A., 2004. Geoelectric investigation of the Ondo State Housing Corporation Estate ljapo Akure, Southwestern Nigeria. Journal of Mining and Geology.Vol. 40(1): 41- 48

Oladapo, M. I. and Akintorinwa, O. J., 2007. Hydrogeophysical Study of Ogbese Southwestern Nigeria Global Journal of Pure and Applied Sciences. 13(1): 55 - 61

Olayinka, A. and Barker, R., 1990. Borehole Siting in Crystalline Basement Areas of Nigeria with a Microprocessor Controlled Resistivity Traversing System. Groundwater, 28: 178-183.

Olayinka, A.. I. and Olorunfemi, M. O., 1992. Determination of geoelectrical characteristics in Okene area and implications for borehole siting. Journal of Mining and Geology, 28(2): 403 - 412.

Olorunfemi, M.O. and Olorunniwo, M. A., 1985. Geoelectric parameters and aquifer characteristic of some parts of Southwestern Nigeria. J.Min. Geol., 35 (2): 207228

Omosuyi, G.O., Ojo, J.S. and Enikanselu, P. A., 2003. Geophysical Investigation for groundwater around Obanla-Obakekere in Akure area within basement complex Southwestern Nigeria. J. Min. Geol. 39 (2): $109-116$.

Rahaman, M. A., 1976. Review of the basement geology of southwestern Nigeria: In Geology of Nigeria (Kogbe, C .A. Ed). Elizabethan Publ. Co., Nigeria pp. 41-58.

Satpathy, B. N. and Kanungo, B. N., 1976. Groundwater exploration in hard rock terrain- A case study. Geophysical prospecting, 24 (4): 725-763.

Vander Velper, B.P.A., 1988. Resist version 1.0 M.Sc Research project, ITC, Delft, Netherlands.

Verma, R.K., Rao, M. K. and Rao, C. V., 1980. Resistivity investigations for groundwater in metamorphic areas near Dhanbad, India. Ground Water, 18 (1): 46-55.

Yang, C., Tong, L. and Jeng, L.,, 1994. Locating groundwater at selected sites by geoelectric methods: Annual Meeting Abstracts, Society of Exploration Geophysicists, 652-654.

Zohdy, A. A. R., 1969. The Use of Schlumberger and Eqatorial Soundings in Groundwater Investigations near El Paso, Texas. Geophysics, 34: 713-728. 